\title{
Pork production technology optimization based on mathematical modelling
}

\author{
Nataliya Kulmakova ${ }^{1}$, Victor Orlov $^{2, *}$, Alexander Ivanitskiy $^{3}$, Nadezhda Sevastyanova ${ }^{4}$ and \\ Sayana Mongush $^{5}$ \\ ${ }^{1}$ Russian State Agrarian University - Moscow Timiryazev Agricultural Academy, Timiryazevskaya \\ st., 49, Moscow, 127550, Russia \\ ${ }^{2}$ Moscow State University of Civil Engineering, Yaroslavskoe shosse, 26, Moscow, 129337, Russia \\ ${ }^{3}$ Chuvash State University named I.N. Ulyanov, Moscow str. 15, Cheboksary, 428000, Russia \\ ${ }^{4}$ Moscow University of Finance and Law, 8 Presnenskaya Embankment, Capital City Tower, 9th \\ Floor, Moscow, 123317, Russia \\ ${ }^{5}$ Tuvan State University, Lenina str. 36, Kyzyl, 667000, Russia
}

\begin{abstract}
One of the ways to enhance sow productivity is to use various food supplements to stimulate digestion and uptake of the elements required for the accelerated development of animals. The list of such supplements is expanding every year and, according to experiments conducted, they yield good results. However, their controversial manifestation in the pork production process should be noted. The used supplements clearly affect this process optimality both in terms of the output and financial outlays. This work addresses the influence of proteinvitamin-mineral supplements (PVMS) on sow productivity, metabolism, and pork quality. The mathematical model has been used to substantiate the optimal alternative of the pork production technology for the PVMS under study. Addition of Provimi supplements to the pig diet has been found to enhance litter heaviness, sow milking capacity, the viability of piggery by the time of weaning, and to promote the growth of the young stock. In the bodies of piggery and sows, the use of supplements normalizes cobalt, manganese, and copper metabolism, increases the content of gamma globulins in the piggery serum, and improves pork nutritional and biological value.
\end{abstract}

\section{Introduction}

In 2011, the Russian Ministry of Agriculture elaborated the "Strategy of meat husbandry in the Russian Federation until 2020", that provides for as follows: further increase in home production of pork (dressed weight) to $3.3 \mathrm{mln}$ tons by 2020 , in per capita terms - from 16.1 to $28.2 \mathrm{~kg}$; export promotion and increase, starting from 2014, to 200 th. tons by 2020; increase in pork share in overall meat resources from $32 \%$ to $37 \%$. The gain in pork production will result in increased consumption of feed grain from 12 to $16 \mathrm{mln}$ tons a year. The main gain $(80 \%)$ in pork production is assumed to be secured by production fattening capacities, commissioning of new integrated closed-cycle production

\footnotetext{
* Corresponding author: orlovvn@mgsu.ru
} 
sites, processing and trading in co-operation with small and medium businesses, increase in the genetic potential of meat productivity of the fattening pig stock with regard to advanced capabilities of selection and genetic centers being set up.

With intensive pig breeding, there is a very high demand for brand new effective preparations capable of enhancing animal resistance and productivity. However, they are not widely used at Russian livestock husbandries due to their unstable efficacy, side-effects, lack of knowledge as to their mechanism of action, need to use high-protein diet or high costs [1-5].

Provimi (the Netherlands) has developed six main groups of fodder concentrates, or protein-vitamin-mineral supplements: "Superprestarter" - ready-made feed for sucker pigs, "Starter" - for weanlings, "Grower" - for growing-finishing pigs, "Finisher" - for fattening pigs, SB - for bred sows and SL - for lactating sows and he-swines. Besides, the company produces PVMS for replacements and sow milk substitute for piggery.

The objective of this work is to study the influence of PVMS by Provimi on sow productivity and use the mathematical model to substantiate the optimal pork production process.

\section{Study materials and methods}

A scientific and economic experiment was conducted by making up two cohorts of sows and two cohorts of their piggery by the analogue pair method (experimental and control), 10 heads in each.

Control animals were given the stock diet according to the commonly used method. Experimental animals were additionally given PVMS in line with the Provimi program.

Protein-vitamin-mineral supplement SB 1627 for pregnant pigs used in line with the Provimi program in combination with grain is an all-in-one feed that allows to improve piggery prenatal development in the second half of pregnancy as much as possible and smoothly restore the condition of sows after weaning.

Mixed feed with PVMS SL 1629 is fed one week before farrowing; it improves piggery prenatal development as its composition is different from that of mixed feed SB (table 1). It contains more protein, energy, amino acids and less fiber.

Table 1. Composition of PVMS SB 1627 and SL 1629.

\begin{tabular}{|l|c|c|c|}
\hline \multicolumn{1}{|c|}{ Nutrient content } & UoM & SB 1627 & SL 1629 \\
\hline $\begin{array}{l}\text { Percentage added to mixed } \\
\text { feed }\end{array}$ & $\%$ & 10 & 15 \\
\hline Metabolizable energy & $\mathrm{kkal} / \mathrm{kg}$ & 1,950 & 2,410 \\
\hline Crude protein & $\mathrm{g} / \mathrm{kg}$ & 282.5 & 370.0 \\
\hline Crude fiber & $\mathrm{g} / \mathrm{kg}$ & 102.0 & 97.0 \\
\hline Crude fat & $\mathrm{g} / \mathrm{kg}$ & 21.0 & 44.0 \\
\hline Ash & $\mathrm{g} / \mathrm{kg}$ & 337.0 & 259.0 \\
\hline Lysin & $\mathrm{g} / \mathrm{kg}$ & 17.6 & 33.4 \\
\hline Methionine + cystine & $\mathrm{g} / \mathrm{kg}$ & 9.0 & 1.05 \\
\hline Calcium & $\mathrm{g} / \mathrm{kg}$ & 64.4 & 55.8 \\
\hline Phosphorus & $\mathrm{g} / \mathrm{kg}$ & 20.0 & 24.0 \\
\hline Sodium & $\mathrm{g} / \mathrm{kg}$ & 25.0 & 12.0 \\
\hline Copper & $\mathrm{g} / \mathrm{kg}$ & 0.2 & 0.13 \\
\hline Chlorides & $\mathrm{g} / \mathrm{kg}$ & 9.5 & 8.5 \\
\hline Vitamin A & $\mathrm{IU}$ & 100.000 & 66.500 \\
\hline Vitamin $\mathrm{D}_{3}$ & $\mathrm{IU}$ & 20.000 & 13.350 \\
\hline Vitamin E & $\mathrm{mg} / \mathrm{kg}$ & 200 & 267 \\
\hline
\end{tabular}


Protein-vitamin-mineral supplements are added to the animal diet with concentrated feeds and are fed daily over the entire observation period.

The mixed feed contains $60 \%$ of wheat, $30 \%$ of barley, $10 \%$ of PVMS SB 1627 . During the first 60 days of pregnancy, sows are fed $2.5 \mathrm{~kg}$, from 60 to 85 days $-3 \mathrm{~kg}$, and from 85 to 105 days $-3.5 \mathrm{~kg}$ of mixed food.

10 days before farrowing, mixed feed with PVMS SL 1629 is fed in the amount of $3 \mathrm{~kg}$ per head a day; after farrowing, $0.5 \mathrm{~kg}$ is additionally fed per pig from the litter. The mixed feed contains $25 \%$ of wheat, $60 \%$ of barley, $15 \%$ of PVMS SB 1627 . During farrowing, the amount of the feed is reduced to $2 \mathrm{~kg}$.

After farrowing, the feed amount per milking sow is gradually increased from 2 to $5 \mathrm{~kg}$ over 5 days. By the end of the second day of lactation, sows are fed up to $7 \mathrm{~kg}$ of feed with PVMS SL 1629 and this amount is given until weaning, which allows sows to go through lactation with the least live weight loss.

One day after weaning, sows are not fed, only unlimited amount of water is given. After weaning, a sow continues to be fed mixed feed with PVMS SL 1629 in the amount of 3.5 $\mathrm{kg}$ until the first mating, after which the cycle is repeated.

In case of not-in-pig, a sow gets $3.5 \mathrm{~kg}$ of the mixed feed with PVMS SL 16295 days before remating. Next, it gets $2.5 \mathrm{~kg}$ of the feed with PVMS SB 1627. After the third notin-pig, sows are discarded.

When analyzing the diet for pregnant sows, it should be noted that it covered the animal demand for EFU, crude and digestible protein, $\mathrm{Ca}, \mathrm{P}$, vitamin $\mathrm{B} 1$. Deficiency of $\mathrm{Fe}, \mathrm{Cu}, \mathrm{Zn}$, $\mathrm{Mn}, \mathrm{Co}, \mathrm{J}$ and vitamins $\mathrm{A}, \mathrm{D}, \mathrm{E}, \mathrm{B} 2, \mathrm{~B} 3, \mathrm{~B} 4, \mathrm{~B} 5$ and B12 was made up for with premix $\mathrm{P}$ 53-1 in the amount of $1 \%$ of the feed weight. The diet for milking sows was also enriched with premix P 53-1.

The diet of lactating sows was balanced by digestible protein, methionine + cystine, calcium, phosphorus, vitamin B1. Deficiency of trace elements and vitamins was made up for with premix P 53-1 added in the amount of 1\% of the feed weight.

After sowing, pigs were fed mixed feed with PVMS SB 10\% in line with the scheme for pregnant sows according to the Provimi feeding program.

One of the main elements in the pig fattening method is rationed full-value feeding. Genetic productivity potential of stores may be implemented subject to complete satisfaction of the demand for nutrients at all development stages.

Biological inadequacy of the diet is known as a driver of animal growth and development depression, which hampers growth and development.

Grain feeds that form the basis of the pig diet are also known to not cover the demand for required nutrients. Pregnancy is accompanied by intensive deposition of nutrients in the body. Live weight gain is also ensured by the fetal growth and development.

Changes in the sow live weight during pregnancy are provided in table 2.

Table 2. Changes in the sow live weight during pregnancy.

\begin{tabular}{|l|c|c|c|}
\hline \multirow{2}{*}{ Cohorts $(n=10)$} & \multicolumn{2}{|c|}{ Sow live weight, kg } & \multirow{2}{*}{$\begin{array}{c}\text { ive weight gain during } \\
\text { pregnancy, } \mathrm{kg}\end{array}$} \\
\cline { 2 - 3 } & after sowing & at the end of pregnancy & $37.80 \pm 1.50$ \\
\hline Experimental & $227.84 \pm 1.81$ & $265.64 \pm 1.19$ & $30.80 \pm 1.60^{* *}$ \\
\hline Control & $230.23 \pm 2.23$ & $261.03 \pm 0.97$ & \\
\hline
\end{tabular}

\section{Results}

The study has shown that experimental animals deposited nutrients more intensively. At the onset of pregnancy, the live weight of sows was at the same level - 227.84 \pm 1.81 $230.23 \pm 2.23 \mathrm{~kg}$. The difference between live weight gain in experimental and control sows was $7.0 \mathrm{~kg}$ or $18.5 \%(\mathrm{P}<0.01)$, which we attribute to the addition of PVMS by Provimi. 
The live weight of sows in the suckling period is known to interrelate to the milking capacity. During intensive lactation, nutrient reserves in the bodies of sows become predecessors to milk production, which results in their decreased live weight. With inadequate diet, this results in attrition of sows and their reduced productivity. This is why, the role of biologically active supplements in the sow diet increases in this period. Their addition to the inadequate diet helps prevent animal attrition and stimulates physiologic processes in the body.

Sucker pigs receive all the nutrients required for their growth and development with mother's milk. This is why it has to have high nutrient value and cover the main needs of sucker pigs.

Sow live weight dynamics during the suckling period is provided in table 3 , from which it follows that lactation is accompanied by live weight loss. This process is more intense in control sows.

After farrowing, the live weight in experimental sows was $252.17 \pm 1.19 \mathrm{~kg}$ and in control sows $-249.34 \pm 1.07 \mathrm{~kg}$. After weaning, the difference in the cohorts was $6.28 \mathrm{~kg}$. The highest live weight loss was observed in control sows $-20.61 \pm 1.26$ versus $17.16 \pm 1.16$ $\mathrm{kg}$ in experimental sows, with a difference of $16.74 \%(\mathrm{P}<0.01)$.

Table 3. Changes in the sow live weight during the suckling period.

\begin{tabular}{|l|c|c|}
\hline \multirow{2}{*}{ Indicators } & \multicolumn{2}{c|}{ Cohorts $(n=10)$} \\
\cline { 2 - 3 } & Experimental & Control \\
\hline Sow live weight after farrowing, $\mathrm{kg}$ & $252.17 \pm 1.19$ & $249.34 \pm 1.07$ \\
\hline Sow live weight 60 days after farrowing, $\mathrm{kg}$ & $235.01 \pm 1.33$ & $228.73 \pm 1.24$ \\
\hline $\begin{array}{l}\text { Loss in sow live weight during the suckling period, } \\
\mathrm{kg}\end{array}$ & $17.16 \pm 1.16$ & $20.61 \pm 1.26$ \\
\hline
\end{tabular}

Thus, milk production in control sows in the lactation period was ensured not only by the nutrients received from the feed, but the lack of substances was compensated by the mother's body with the nutrients contained in own body cells and tissues. Experimental sows were in a better position as their diet comprised PVMS by Provimi.

The effectiveness of feed supplements in the pregnant and milking sow keeping method was assessed by multiple fetation and litter heaviness, litter weight at birth and weaning, milking capacity, piggery viability (table 4 ).

Table 4. Sow productivity.

\begin{tabular}{|l|c|c|c|}
\hline \multirow{2}{*}{\multicolumn{1}{|c|}{ Indicators }} & \multicolumn{2}{c|}{ Cohorts $(n=10)$} & \multirow{2}{*}{$\mathrm{P}$} \\
\cline { 2 - 3 } & Experimental & Control & \\
\hline Multiple fetation, heads & $11.27 \pm 0.12$ & $10.71 \pm 0.56$ & \\
\hline Heavy litter, kg & $1.30 \pm 0.08$ & $1.02 \pm 0.05$ & $<0.01$ \\
\hline Milking capacity, kg & $54.82 \pm 1.49$ & $52.46 \pm 0.50$ & \\
\hline Piggery viability by weaning, \% & 90.5 & 88.0 & \\
\hline Total litter weight by weaning, kg & $176.56 \pm 2.05$ & $149.02 \pm 2.10$ & $<0.001$ \\
\hline Pig live weight by weaning, kg & $17.31 \pm 0.08$ & $15.82 \pm 0.13$ & $<0.001$ \\
\hline
\end{tabular}

Multiple fetation is an important economic trait of pigs. In our studies, multiple fetation in the cohorts did not show significant difference and was $10.71 \pm 0.56 \mathrm{~kg}$ in the experimental cohort, $5 \%$ lower than the control cohort.

Litter heaviness is of the utmost importance for further animal development and productivity. Numerous studies have ascertained that the pigs that are larger at birth outperform their lightweight congeners by virtually all development and productivity indicators. The biggest pigs were born in the experimental cohort, weight $1.30 \pm 0.08 \mathrm{~kg}$. The difference in litter heaviness between the cohorts was $21.5 \%(\mathrm{P}<0.01)$. 
Sow milking capacity in the cohorts varied from 54.82 to $52.46 \mathrm{~kg}$, which is $4.3 \%$ higher in experimental sows compared to control ones.

Under the influence of PVMS, pig viability by weaning amounted to $90.5 \%$ versus $88 \%$ in the control cohort.

From analysis of the data of the pig live weight by weaning, we can conclude that the pigs from experimental sows had a $8.6 \%$ bigger weight compared to the control cohort $(\mathrm{P}<0.01)$. The total litter weight by weaning amounted to $176.56 \pm 2.05$ versus $149.02 \pm 2.10$ $\mathrm{kg}(\mathrm{P}<0.00)$.

The reproductive function was better in experimental sows (table 5).

Table 5. Sow reproductive function indicators.

\begin{tabular}{|l|c|c|}
\hline \multirow{2}{*}{ Indicators } & \multicolumn{2}{c|}{ Cohorts $(n=10)$} \\
\cline { 2 - 3 } & Experimental & Control \\
\hline Period from weaning to the first estrus, days & $14.6 \pm 2.9$ & $18.8 \pm 2.5$ \\
\hline Conception rate on first breeding, \% & 70 & 62.5 \\
\hline Period between farrows, days & $184.8 \pm 2.3$ & $193.9 \pm 3.1^{*}$ \\
\hline
\end{tabular}

The period from weaning to the first estrus decreased by 4.2 day; period between farrows - by 9.1 day or $5.1 \%$. Conception rate on first breeding grew by $7.5 \%$.

Analysis of the data obtained shows that addition of PVMS SB 1627 and SL 1629 to mixed feeds from the first day of mating until weaning enhances sow productivity, conception rate and shortens the period between farrows.

It is known that within the same breed, larger litter are yielded by big sows that have high growth and development indicators. Changes in sow productivity depending on the number of farrows are shown in table 6.

Table 6. Sow productivity dependence on the number of farrows.

\begin{tabular}{|c|c|c|c|c|c|c|}
\hline \multirow[b]{2}{*}{$\begin{array}{l}\text { No. of } \\
\text { farrows }\end{array}$} & \multirow[b]{2}{*}{$\begin{array}{c}\text { Multiple } \\
\text { fetation, } \\
\text { heads }\end{array}$} & \multirow[b]{2}{*}{$\begin{array}{c}\text { Litter } \\
\text { heaviness, } \\
\mathrm{kg}\end{array}$} & \multicolumn{2}{|c|}{$21^{\text {st }}$ day of lactation } & \multicolumn{2}{|c|}{ At months } \\
\hline & & & $\begin{array}{l}\text { Milking } \\
\text { capacity, } \mathrm{kg}\end{array}$ & $\begin{array}{c}\text { Pig } \\
\text { viability, } \\
\%\end{array}$ & $\begin{array}{l}\text { Daily average } \\
\text { weight gain in } \\
\text { pigs, } g\end{array}$ & $\begin{array}{c}\text { Pig } \\
\text { viability, } \\
\%\end{array}$ \\
\hline 1 & $10.14 \pm 0.42$ & $1.16 \pm 0.07$ & $51.43 \pm 2.09$ & $98.62 \pm 1.71$ & $270.67 \pm 3.83$ & $97.23 \pm 1.89$ \\
\hline 2 & $10.71 \pm 0.42$ & $1.39 \pm 0.14$ & $49.34 \pm 1.17$ & $93.37 \pm 1.89$ & $253.00 \pm 4.16$ & $90.66 \pm 2.03$ \\
\hline 3 & $10.86 \pm 0.42$ & $1.49 \pm 0.06$ & $49.63 \pm 1.59$ & $86.83 \pm 1.78$ & $279.50 \pm 5.47$ & $86.83 \pm 1.75$ \\
\hline 4 & $10.57 \pm 0.85$ & $1.37 \pm 0.05$ & $52.07 \pm 1.71$ & $90.54 \pm 1.36$ & $265.17 \pm 2.83$ & $89.21 \pm 2.35$ \\
\hline 5 & $10.60 \pm 1.17$ & $1.33 \pm 0.09$ & $50.56 \pm 2.38$ & $84.91 \pm 1.54$ & $273.67 \pm 3.71$ & $84.90 \pm 1.96$ \\
\hline
\end{tabular}

Following long-term use of protein-vitamin-mineral supplements by Provimi in sow diets, we obtained the following productivity results. In the farrowing dynamics (first to fifth), multiple fetation ranged from $10.14 \pm 0.42$ to $10.86 \pm 0.42$.

The live weight of born pigs increased from the first to the third farrowing and amounted to $1.49 \pm 0.06 \mathrm{~kg}$; next, by the fifth farrowing, it decreased by $10.7 \%$. However, this weight was bigger than with the first farrowing.

Analysis of milking capacity has shown that it ranged from $49.34 \pm 1.17$ with the second farrowing to $52.07 \pm 1.71 \mathrm{~kg}$ to the fourth one.

Young stock viability by weaning was higher with the first sow farrowing and amounted to $98.62 \pm 1.71 \%$.

Higher growth power was observed in piggery from the third farrowing; their daily average weight gain from birth to 60 days of age was $279.5 \pm 5.47 \mathrm{~g}$, which was $10.5 \%$ higher than in herd mates of the second farrowing.

Thus, the increase in multiple fetation, the yield of piggery livestock and live weight by weaning in sows of 2-5 farrows may be explained by improved placental nutrition in the prenatal period under the influence of PVMS by Provimi. 
As it appears from publications, all the developments in animal production are subject to experimental studies, the results of which are used to build certain process hypotheses. One of effective tools to substantiate these hypotheses is mathematical modeling, which is successfully used in various areas of human activity - fundamental research [6], construction [7-9], animal production $[3,10,11,12]$, medicine $[13,14]$, education $[15,16]$, economy [17]. As it follows from publications [3,10,11,12] and results presented in this work, various developments of biologically active supplements yield controversial results that affect the manufacturing process. An experiment was also conducted with Provimi preparations: five farrows were obtained from the experimental cohort of sows to identify their efficacy and an optimal number of farrows in the pig reproduction process. The experiment considered the following indicators: multiple fetation, litter heaviness, viability on the 21 st day, average weight gain, viability in two months of age. This information was used to build two mathematical models. The first - to validate the mathematical modeling method with a testing check of the hypothesis proposed. The model is based on experimental data of the experimental cohort of sows, which is reduced to indicators of an average weighted sow and which implicitly reflects all the above experimental data of the experimental cohort of sows. The supplement time-series model processing method was used to build the mathematical model

$$
\mathrm{Y}=\mathrm{T}+\mathrm{S}+\mathrm{E}
$$

where $\mathrm{Y}$ is the weight of a litter of an average weighted experimental sow, $\mathrm{S}$ is a cyclical component obtained using the moving average method and representing the composite weight of the litter, $\mathrm{T}$ is a trend component, which is the second element of the litter weight, $\mathrm{E}$ is a random component that comprises the factors affecting the litter weight that have been ignored in the process. These values are measured in $\mathrm{kg}$. The trend component looks as follows:

$$
\mathrm{T}=50.0583+0.2267 \mathrm{t}
$$

where $t$ is the number of farrows. Geometrical interpretation of the source data of four farrows and the model built is shown in figure 1, where row 1 corresponds to the source data and row 2 - to the model built. With point prediction of the first model, the fifth farrowing yields $\mathrm{Y} 5=50.923 \mathrm{~kg}$. The actual experimental value of the fifth farrowing is $\mathrm{Y} 5=50.550 \mathrm{~kg}$.

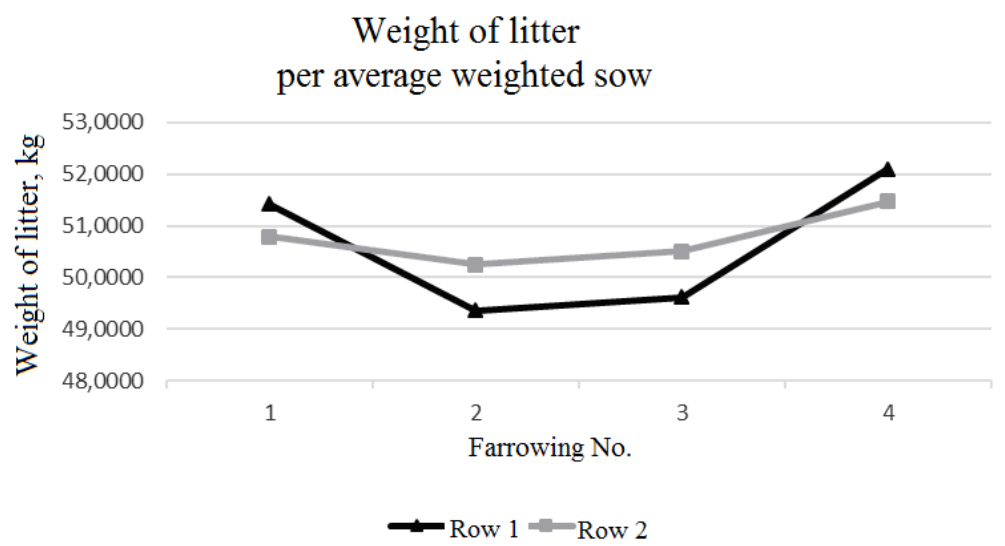

Fig. 1. Litter weight dependence on the farrowing number.

The second model based on the results of five farrows of the experimental cohort is intended to substantiate the optimal process alternative using the results of the prediction 
based on the variance analysis provided in [18]. Geometrical interpretation of the source data and the model built is shown in figure 2: row 1 - source data, row 2 - model built. The structure of the second model is similar to that of the first. The trend component looks as follows:

$$
\mathrm{T}=49.5383+0.3117 \mathrm{t}
$$

The confidence of the trend component was determined based on Student criterion, confidence level $\alpha=0.05 ; \mathrm{t}_{\text {crit }}=2.776 ; \mathrm{t}_{\text {observ }}=5.367$ and assumption of competing hypothesis $\mathrm{H}_{1}: \mathrm{b} \neq 0$, where $\mathrm{b}=0.3117$ coefficient of trend component $\mathrm{T}$. The quality measure of the model built is $\mathrm{R}_{2}=0.9813$. The confidence interval of the value predicted for the sixth farrowing is $49.779 \leq \mathrm{Y}_{6} \leq 51.671$.

\section{Weight of litter per average weighted sow}

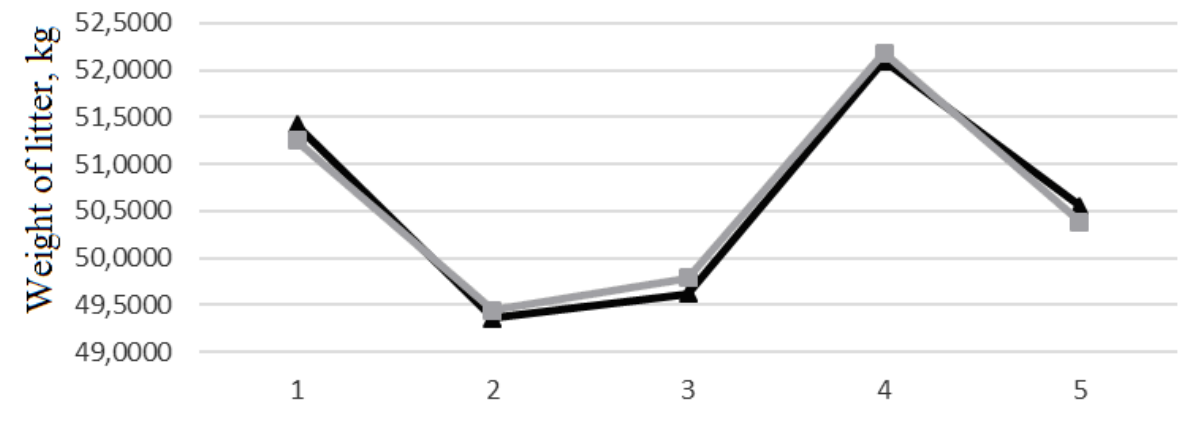

Farrowing No.

$\longrightarrow$ Row $1=$ Row 2

Fig. 2. Litter weight dependence on the farrowing number.

Calculations show that the maximal result of the fourth farrowing is outside of the confidence interval obtained.

\section{Discussion}

Publications [19-24], the authors of which studied the use of different biologically active substances and feed supplements at different stages of the animal breeding process and results of our experiment evidence the effectiveness of PVMS in animal breeding. At the same time, it should be noted that the studies conducted [19-24] did not use mathematical modeling tools to substantiate experimental results. Quality results of the mathematical model built and prediction results were derived from the author's development based on variance analysis [18]. Based on the quality measure of the mathematical model built, it is fair to say that the optimal number of farrows is four. According to the results of $[3,12]$, the optimal number of farrows for Provimi is one unit bigger. One should mention a slower effect of Provimi on sows compared to Selmic [3] and Microlact [12]. The litter weight per an average weighted sow with the fourth farrowing for Provimi and with the third farrowing for Microlact and Selmic is, correspondingly, $52.1 \mathrm{~kg}, 54.8 \mathrm{~kg}$ and $54.82 \mathrm{~kg}$, which proves their efficacy. 


\section{Conclusion}

Thus, we have observed controversial in terms of its quality influence of different PVMS on the pork production process. The use of a modern technique - mathematical modelling yields rigorous substantiation of the results obtained and allows us to propose the optimal process alternative.

\section{References}

1. N.I. Kulmakova, V.N. Orlov, Bulletin of the Izhevsk State Agricultural Academy 3(52), 23-29 (2017)

2. N.I. Kulmakova, Siberian Bulletin of Agriculture 3-4, 83-88 (2011)

3. N.I. Kulmakova, V.N. Orlov, Bulletin of the Kurgan State Agricultural Academy 2(18), 40-43 (2016)

4. N.I. Kulmakova, Doctoral thesis in Agricultural Sciences (Cheboksary, 2011)

5. N.A. Lyubin, S.V. Dezhatkina, et.al. Development of non-traditional natural biologically active substances and their introduction into animal husbandry (Ulyanovsk, 2017)

6. V.N. Orlov, S.A. Redkozubov, News of the Engineering Physics Institute 4(18), 2-6 (2010)

7. O.A. Kovalchuk, Procedia Engineering 153-2, 304-309 (2016)

8. O.A. Kovalchuk, J. of Industrial and Civil Construction 9, 70-73 (2016)

9. O.A. Kovalchuk, J. of Industrial and Civil Construction 11, 53-54 (2014)

10. N.I. Kulmakova, L.B. Leontyev, Bulletin of Stavropol agro-industrial complex 3(19), 104-107 (2015)

11. N.I. Kulmakova, L.B. Leontyev, News of the Timiryazev Agricultural Academy 3, 5764 (2015)

12. N.I. Kulmakova, V.N. Orlov, Innovations in the agro-industrial complex: prospects and challenges (Belgorod State Agricultural Academy) 4(12), 130-137 (2016)

13. V.N. Orlov, Disease Prevention and Health Promotion (Moscow) 5, 44-47 (007)

14. V.N. Orlov, Kazan Medical J. 90-6, 889-892 (2009)

15. V.N. Orlov, N.Ye. Pikina, Informatics and Education 1, 109-110 (2008)

16. V.N. Orlov, N.Ye. Pikina, Solutions Proc. of the Research and Practical Conference (Branch of the Saint-Petersburg University of Economics Cheboksary, 2009)

17. V.N. Orlov, T.V. Ivanova, Economics of Agricultural and Processing Enterprises 12, 73-77 (2016)

18. V.N. Orlov, Bulletin of the Russian State Social University (Cheboksary branch) 1(30), 128-129 (2014)

19. E. Stachurova, M. Certik, V. Buleca, S. Marclncak, Folia veterinaria (Univ. of veterinary medicine, Kosice) 54-2, 82-84 (2010)

20. Y. Sasaki, J. Japan veter. med. assn. 63(3), 187-190 (2010)

21. A. Rivera, J.L. Figueroa, E. Saldana, Arch. Zootecn. 59(227), 357-368 (2010)

22. D.C. Mahan, J. anim. Sc. 68-2, 573-582 (1990)

23. N. Godfrey, Choosing pig feeds. South Perth (Farmnote, Western Austral, 1988)

24. F.X. Aherne, Hog J. 17(4), 37-38 (1996) 